Sci. Journal Impact

Factor: 6.1 (2018)

ICV: 90.90 (2018)

(c) (i) (3)

Copyright@IJCRR

\section{$\nabla$ \\ IJCRR \\ Section: Healthcare \\ Awareness Among College Students Towards Covid-19 and its Effects on the Cardiovascular System - A Survey}

\author{
Harini M ${ }^{1}$, Gayatri Devi², Gayathri $\mathbf{R}^{3}$
}

\begin{abstract}
'Saveetha Dental College and Hospitals, Saveetha Institute of Medical and Technical Sciences (SIMATS), Saveetha University, Chennai, India; 'Assistant Professor, Department of Physiology, Saveetha Dental College and Hospitals, Saveetha Institute of Medical and Technical Sciences (SIMATS), Saveetha University, Chennai, India; ${ }^{A}$ Assistant Professor, Department of Biochemistry, Saveetha Dental College and Hospitals, Saveetha Institute of Medical and Technical Sciences (SIMATS), Saveetha University, Chennai, India.
\end{abstract}

\title{
ABSTRACT
}

Introduction: COVID-19 is a respiratory syndrome affecting countless numbers of lives all over the world. It is reportedly caused due to the SARS-CoV-2 virus which is known to impair the lower respiratory tract causing distress. ACE2 receptors are the functional receptors of SARS-CoV-2 and are present in the lungs and heart majorly thereby causing acute cardiovascular diseases. The aim of this study is to spread awareness about the COVID-19 and its effects on the cardiovascular system.

Materials and Method: A questionnaire was distributed through an online Google form link to about 100 people of a dental college belonging to age groups between 17-23 years of age. The study population was asked to fill out the forms. The results were collected and the data was analyzed using SPSS version 20.

Result and Discussion: From the study population, the whole of $100 \%$ of the participants gave a positive response when asked if they were aware of COVID-16 and its effects although the majority of the study population was not aware of its effects in the cardiovascular system.

Conclusion: By this survey, it can be concluded that a more severe approach to the awareness of COVID-19 and its various effects on the cardiovascular system could be administered among the population for the betterment of lifestyle and health.

Key Words: COVID-19, Effects, Cardiovascular system, Awareness, college students, ACE2 receptors

\section{INTRODUCTION}

COVID-19 is a respiratory syndrome affecting countless numbers of lives all over the world. It is reportedly caused due to the SARS-CoV-2 virus which is known to impair the lower respiratory tract causing distress ${ }^{1}$. It is reported to date (May 2020), that over 4 million laboratory-confirmed cases of COVID-19 have been reported worldwide in about 187 countries ${ }^{2}$. Available evidence suggests that COVID-19 is found to having a natural origin and is transmitted by inhaling the droplets expelled from the sputum of infected patients ${ }^{3}$. The major clinical characteristics associated with COVID-19 disease as reported by patients from China ${ }^{4,5}$, South Korea ${ }^{6}$, and the United States ${ }^{7}$ have mentioned dry cough, fever, and shortness of breath being the most common clinical features. The diagnosing tests for detection of COVID-19 include detecting the genetic material RNA in a naso- pharyngeal swab or by a sputum sample ${ }^{8}$, antibody tests ${ }^{9}$, and detecting viral proteins (antigens) ${ }^{10}$. According to Ying Ying Zheng et al. (2020) states that SARS-CoV-2 is found to infect host cells through the ACE2 receptors which ultimately cause COVID-19 disease. It is also found that ACE2 receptors are present mostly in the lungs and especially in the cardiovascular system and thereby causes diseases such as pneumonia, acute myocardial injury, and chronic damage to the cardiovascular system ${ }^{11}$. Manish Bansal (2020) states that acute cardiac injury which is the significant elevation of cardiac troponin is the most commonly reported cardiac abnormality pertaining to COVID-19 ${ }^{12}$. It is noted that patients who have underlying cardiovascular disease are at a higher risk of acquiring COVID-19 and also fatality due to COVID- $19^{13}$. The cardiac injury seems to contribute to $40 \%$ of total deaths related to COVID-19 ${ }^{14}$.

\section{Corresponding Author:}

Dr. R. Gayatri Devi, Assistant Professor, Department of Physiology, Saveetha Dental College and Hospitals, Saveetha Institute of Medical and Technical Sciences (SIMATS), Saveetha University, 162, Poonamallee High Road, Chennai-600077, Tamilnadu, India; Phone: +91 8248016505; Email: gayatridevi.sdc@saveetha.com

ISSN: $2231-2196$ (Print) ISSN: 0975-5241 (Online)

Received: $20.07 .2020 \quad$ Revised: 23.08 .2020 Accepted: 16.09 .2020 Published: 20.10 .2020 
Previously our team had conducted numerous clinical trials ${ }^{15-20}$ survey-based studies ${ }^{21,22}$ review based studies ${ }^{23,24}$ and in-vitro studies ${ }^{25-29}$ by students over the past 5 years. Now we are focusing on epidemiological surveys. The idea for this survey stemmed from the current interest in our community. The aim of this study is to spread awareness about the COVID-19 and its effects on the cardiovascular system.

\section{MATERIALS AND METHODS}

A questionnaire was distributed through an online Google forms link (https://forms.gle/UzSrMi818ogoocGfA) to about 100 people of a dental college belonging to age groups between 17-23 years of age. The inclusion criteria included college students, age, sex, and education whereas the exclusion criteria included height, weight, and skin tone of the population. The questionnaire contained various awareness and knowledge-based questions about the assorted effects of COVID-19, especially about its effects pertaining to the cardiovascular system. The selected study population was asked to fill out the forms after reading each question thoroughly. The results were collected and the data was analyzed.

\section{STATISTICAL ANALYSIS}

Statistical test used: Chi square test

Software used: SPSS version 20

\section{COMPLETE QUESTIONNAIRE}

1. Age

2. Gender

3. Are you aware about the current COVID-19 situation?

4. Are you aware of the highly contagious nature of COVID-19?

5. Do you know about the effects of COVID-19 on the human body?

6. Do you know that ACE2 receptors are the functional receptors responsible for SARS-CoV-2 ?

7. Do you know that SARS-CoV-2 is thought to infect host cells through ACE2 to cause COVID-19?

8. Do you know that ACE2 receptors are present in the lungs and especially in the cardiovascular system?

9. Do you know the symptoms of cardiovascular disease?

10. Did you know that ACE2 receptors invade alveolar epithelial cells resulting in respiratory syndromes?

11. Are you aware that COVID-19 can cause acute myocarditis and heart failure?

12. Did you know that COVID-19 is more likely to affect people with underlying cardiovascular disease?
13. Did you know that patients affected by COVID-19 with underlying CVD can aggravate the pneumonia and increase the severity of symptoms?

14. Did you know that patients with CVD and COVID-19 infection have an adverse prognosis?

15. Did you know that according to the mortality data, $17 \%$ of the patients with SATS-CoV-2 had a history of heart disease?

16. Did you know that patients with CVD account for a large proportion of deaths from COVID-19?

17. Did you know that patients with CVD are complex to recover from COVID-19?

18. Did you find this survey useful?

\section{RESULTS AND DISCUSSION}

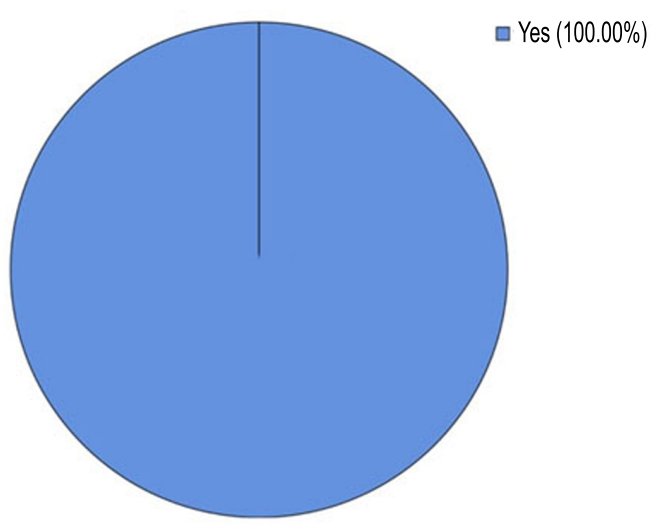

Figure 1: Pie Chart representing the percentage distribution of awareness of the current COVID-19 situation. The total of $100 \%$ respondents (blue) is reported to be aware about the COVID-19 situation.

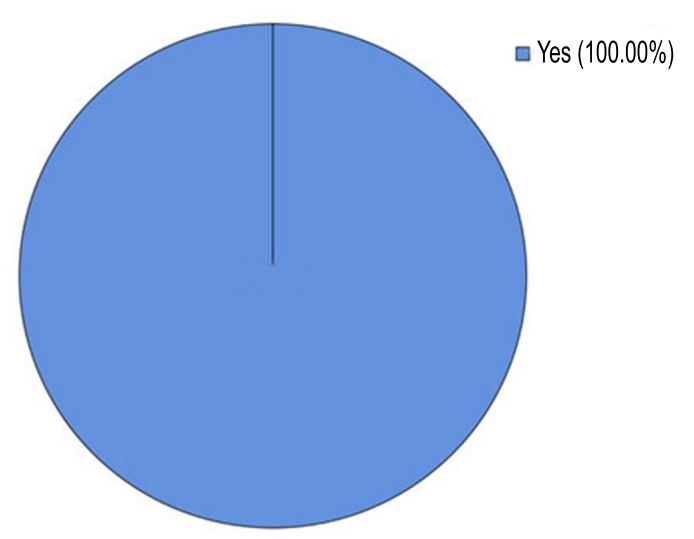

Figure 2: Pie Chart representing the percentage distribution of awareness of the highly contagious nature of COVID-19. The total respondents $(100 \%)$ depicted in blue color are reported to be aware of the highly contagious nature of COVID-19. 


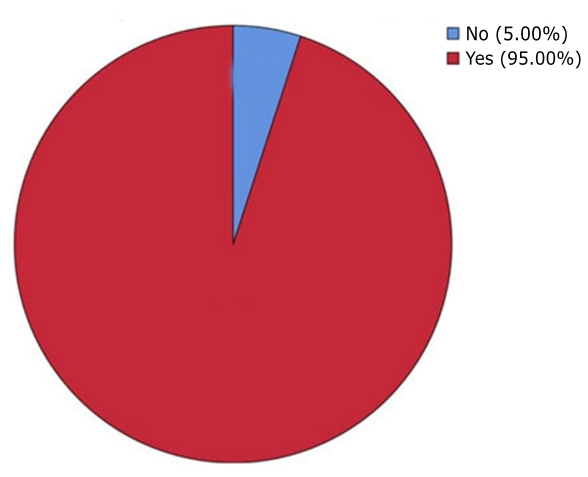

Figure 3: Pie Chart representing the percentage distribution of awareness about the effects of COVID-19 on the human body. The majority of the respondents $(95 \%)$ depicted in the red color have been reported to be aware of the assorted effects of COVID-19 on the human body and 5\% (blue) were not aware.

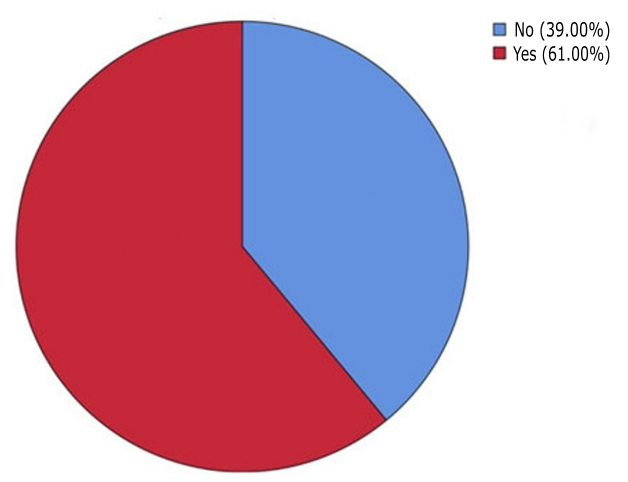

Figure 4: Pie Chart representing the percentage distribution of awareness about the symptoms of cardiovascular diseases. The majority of the respondents $(61 \%)$ depicted in red color have been reported to be aware of the various symptoms of cardiovascular diseases and $39 \%$ were not aware (blue).

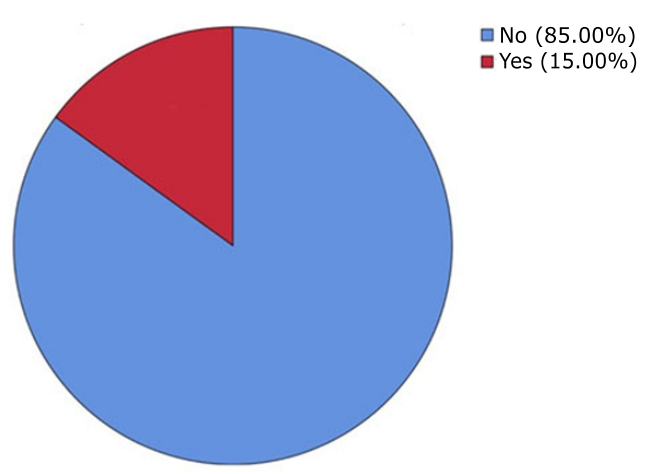

Figure 5: Pie Chart representing the percentage distribution of awareness about COVID-19 can cause acute myocarditis and heart failure. The majority of the respondents (85\%) depicted in blue color have been reported to be aware of the COVID-19 and its effect on the cardiovascular system and the remaining $15 \%$ were not aware (red).

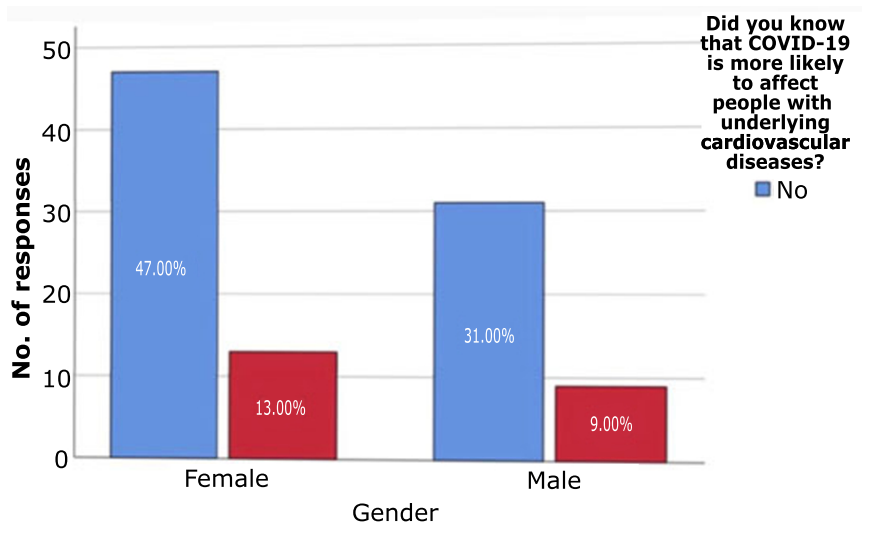

Figure 6: Bar chart showing comparison of responses based on gender and the knowledge that COVID-19 is more likely to affect people with underlying cardiovascular diseases. $\mathrm{X}$-axis represents the gender and $Y$-axis represents the frequency of the knowledge about the effects of COVID-19 who were aware (red) and not aware (blue). Females (47\%) were more aware about the effects of COVID-19 in patients with underlying CVD than males $(31 \%)$. There is no significant difference in the responses between males and females. Pearson's Chi-square value 0.010 and $P$ value $=0.921(>0.05)$. Hence, is statistically insignificant.

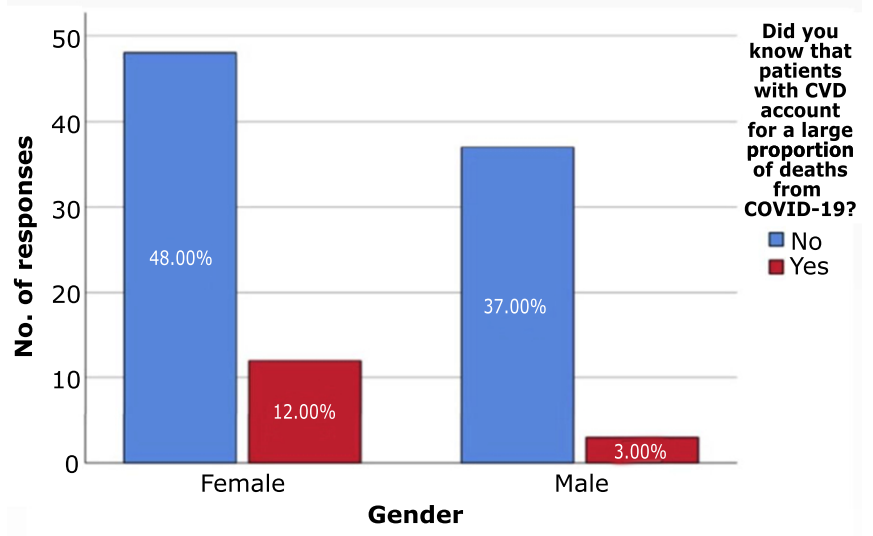

Figure 7: Bar chart showing a comparison of responses based on gender and the knowledge of patients with CVD accounting for a large number of deaths due to COVID-19. X-axis represents the gender and $Y$-axis represents the frequency of knowledge on death due to COVID-19 in patients with underlying CVD who were aware (red) and not aware (blue). Females (48\%) are more unaware than males (37\%). There is no significant difference between males and females. Pearson's Chi-square value $=2.941$ and $P$ value $=0.086(>0.05)$ Hence, statistically insignificant. 


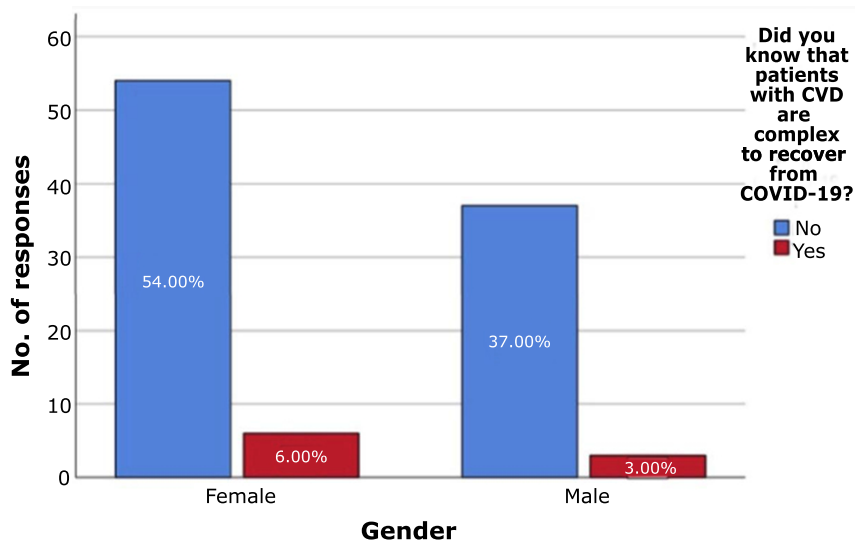

Figure 8: Bar graph showing a comparison of response based on gender and the knowledge that patients with cardiovascular diseases are complex to recover from COVID-19. X-axis represents the gender and $Y$-axis represents the frequency of knowledge about complexity in recovery from COVID-19 in patients with underlying CVD who were aware (red) and not aware (blue). Females (54\%) are more unaware than males (37\%) about the complexity of recovery from COVID-19 in patients with underlying CVD. There is no significant difference between males and females. Pearson's Chi-square value = 0.183 and $P$ value $=0.669(>0.05)$. Hence, is statistically insignificant.

Among the study population, $100 \%$ of the participants had given a positive response when asked if they were aware of the current COVID-19 situation (Fig.1). According to the previous study ${ }^{30}$ it was found that only $22.6 \%$ of the study population was aware of the virus causing COVID-19 and another study ${ }^{31}$, states that about $84 \%$ of the study population was aware of COVID-19 breakdown. When asked if the study population were aware of the highly contagious nature of COVID-19, about $100 \%$ of the participants had given a positive response (Fig.2). According to the study ${ }^{32}$ it had stated that the COVID-19 virus is highly contagious. A study states that about $93.02 \%$ of respondents were aware of the contagious nature of COVID-19 ${ }^{31}$. When asked about the knowledge on the effects of COVID-19, about $95 \%$ of the total participants had given a positive response (Fig.3). An article had stated that ${ }^{32}$, India has the second-highest mortality rate due to the COVID-19 outbreak following China. About $92 \%$ of the participants had given a negative response when asked about their knowledge of ACE2 receptors. From the article by Turner et al. (2020), it can be found that ACE2 receptors are identified as a functional receptor for the COVID-19 disease. The article had also stated that the ACE2 receptors are highly present in the heart and lungs ${ }^{33}$. According to another article, severe acute respiratory syndrome (SARS) infects host cells in the body through the ACE2 receptors present in various organ systems. ${ }^{11}$. When asked about the knowledge of the participants in cardiovascular diseases, $61 \%$ of the participants had given a positive response (Fig.4). According to the study, the general public in Jordan had been found to have limited knowledge and awareness about the assorted cardiovascular diseases, its symptoms, and effects ${ }^{34}$. When asked the study population about their awareness regarding the various effects of COVID-19 on the human body, about $85 \%$ of participants gave a negative response (Fig.5). According to the study by Alhogbani et al. (2020) it had been stated that respiratory syndrome-related COVID-19 causes acute myocarditis and heart failure ${ }^{35}$.

When asked about the risk of acquiring COVID-19 being more prevalent among patients who have a history of cardiovascular disease, about $78 \%$ of the total participants had given a negative response. Chi-square analysis revealed that females $(47 \%)$ were more aware of the effects of COVID-19 in patients with underlying CVD than males (31\%). There is no significant difference in the responses between males and females. The Pearson's Chi-square value $=0.010$ and $\mathrm{P}$ value $=0.921(>0.05)$. Hence, it is considered to be statistically insignificant (Fig.6). According to the study 36 , it has stated that patients with underlying cardiovascular diseases are found to have an increased risk of death from COVID-19. When asked the participants about their awareness about the large proportions of death caused by COVID-19 is majorly accompanied by and is accountable to cardiovascular diseases, about $85 \%$ of the participants had given a negative response. Chi-square analysis revealed that females $(48 \%)$ are more unaware than males $(37 \%)$. There is no significant difference between males and females. The Pearson's Chi square value $=2.941$ and $\mathrm{P}$ value $=0.086(>0.05)$ Hence, it is considered to be statistically insignificant. (Fig.7). According to article ${ }^{37}$, it had been stated that the patients with underlying cardiovascular disease accounts for a large proportion of deaths from COVID-19. When asked if the study population were aware that patients with cardiovascular diseases are complex to recover from COVID-19, about $91 \%$ of the participants had given a negative response. Chi-square analysis revealed that females $(54 \%)$ are more unaware than males (37\%) about the complexity in recovery from COVID-19 in patients with underlying CVD. There is no significant difference between males and females. The Pearson's Chisquare value $=0.183$ and $\mathrm{P}$ value $=0.669(>0.05)$. Hence, it is considered to be statistically insignificant (Fig.8). A previous study states that patients with underlying cardiovascular disease accompanied by SARS-CoV-2 infection have an adverse prognosis ${ }^{11}$

The limitations of this study include the minimal study population. A larger study population could have given varied and more accurate results. The future scope of this article is the possibility of increased awareness of COVID-19 and its effects on the cardiovascular system. 


\section{CONCLUSION}

Through this survey, it can be evidently noted that the majority of the study population is not aware of the various effects of COVID-19 and especially its effects on the cardiovascular system. This act of ignorance among the public could lead to an even wider spread of this virus causing distress. Hence, a widespread awareness of COVID-19 and its various effects on health should be carried out in order to achieve the betterment of public health and lifestyle.

\section{ACKNOWLEDGEMENT}

We thank Saveetha Dental College for providing us the support to conduct the study.

\section{Conflict of Interest}

All the authors declare no conflict of interest in the study.

\section{REFERENCES}

1. Uddin M, Mustafa F, Rizvi TA, Loney T, Suwaidi HA, Al-Marzouqi AHH, et al. SARS-CoV-2/COVID-19: Viral Genomics, Epidemiology, Vaccines, and Therapeutic Interventions. Viruses [Internet]. 2020 May 10;12(5). Available from: http://dx.doi. org/10.3390/v12050526

2. COVID-19 Map [Internet]. Johns Hopkins Coronavirus Resource Center. [cited 2020 Jun 3]. Available from: https://coronavirus.jhu.edu/map.html

3. Andersen KG, Rambaut A, Lipkin WI, Holmes EC, Garry RF. The proximal origin of SARS-CoV-2. Nat Med. 2020 Apr;26(4):450-2.

4. Xie J, Tong Z, Guan X, Du B, Qiu H. Clinical Characteristics of Patients Who Died of Coronavirus Disease 2019 in China. JAMA Netw Open. 2020 Apr 1;3(4):e205619.

5. Yang X, Yu Y, Xu J, Shu H, Xia J 'an, Liu H, et al. Clinical course and outcomes of critically ill patients with SARS-CoV-2 pneumonia in Wuhan, China: a single-centered, retrospective, observational study. Lancet Respir Med. 2020 May;8(5):47581.

6. Prevention C-19 NERCEACMTKCFDCA, COVID-19 National Emergency Response Center, Epidemiology and Case Management Team, Korea Centers for Disease Control and Prevention. Early Epidemiological and Clinical Characteristics of 28 Cases of Coronavirus Disease in South Korea [Internet]. Vol. 11, Osong Public Health and Research Perspectives. 2020. p. 8-14. Available from: http://dx.doi.org/10.24171/j.phrp.2020.11.1.03

7. Team CC-19 R, CDC COVID-19 Response Team, Bialek S, Boundy E, Bowen V, Chow N, et al. Severe Outcomes Among Patients with Coronavirus Disease 2019 (COVID-19) - United States, February 12-March 16, 2020 [Internet]. Vol. 69, MMWR. Morbidity and Mortality Weekly Report. 2020. p. 343-6. Available from: http://dx.doi.org/10.15585/mmwr.mm6912e2

8. Wang Y, Kang H, Liu X, Tong Z. Combination of RT-qPCR testing and clinical features for diagnosis of COVID-19 facilitates management of SARS-CoV-2 outbreak. J Med Virol [Internet]. 2020 Feb 25; Available from: http://dx.doi.org/10.1002/ jmv.25721
9. Li Z, Yi Y, Luo X, Xiong N, Liu Y, Li S, et al. Development and clinical application of a rapid IgM-IgG combined antibody test for SARS-CoV-2 infection diagnosis. J Med Virol [Internet]. 2020 Feb 27; Available from: http://dx.doi.org/10.1002/ jmv. 25727

10. Stadlbauer D, Amanat F, Chromikova V, Jiang K, Strohmeier S, Arunkumar GA, et al. SARS-CoV-2 Seroconversion in Humans: A Detailed Protocol for a Serological Assay, Antigen Production, and Test Setup. Curr Protoc Microbiol. 2020 Jun;57(1):e100.

11. Zheng Y-Y, Ma Y-T, Zhang J-Y, Xie X. COVID-19 and the cardiovascular system. Nat Rev Cardiol. 2020 May;17(5):259-60.

12. Cardiovascular disease and COVID-19. Diabetes \& Metabolic Syndrome: Clinical Research \& Reviews. 2020 May 1;14(3):247-50.

13. Li B, Yang J, Zhao F, Zhi L, Wang X, Liu L, et al. Prevalence and impact of cardiovascular metabolic diseases on COVID-19 in China [Internet]. Vol. 109, Clinical Research in Cardiology. 2020. p. 531-8. Available from: http://dx.doi.org/10.1007/ s00392-020-01626-9

14. Meyer P, Degrauwe S, Van Delden C, Ghadri J-R, Templin C. Typical takotsubo syndrome triggered by SARS-CoV-2 infection. Eur Heart J. 2020 May 14;41(19):1860.

15. Samuel AR, Devi MG. Geographical distribution and occurrence of Endemic Goitre. Research Journal of Pharmacy and Technology. 2015;8(8):973-8.

16. Baheerati MM, Gayatri Devi R. Obesity in relation to Infertility [Internet]. Vol. 11, Research Journal of Pharmacy and Technology. 2018. p. 3183. Available from: http://dx.doi. org/10.5958/0974-360x.2018.00585.1

17. Fathima F, Preetha P. EVALUATION OF THYROID FUNCTION TEST IN OBESE PATIENTS [Internet]. Vol. 9, Asian Journal of Pharmaceutical and Clinical Research. 2016. p. 353. Available from: http://dx.doi.org/10.22159/ajpcr.2016. v9s3.12959

18. Harsha L, Priya J, Shah KK, Reshmi B. Systemic Approach to Management of Neonatal Jaundice and Prevention of Kernicterus [Internet]. Vol. 8, Research Journal of Pharmacy and Technology. 2015. p. 1087. Available from: http://dx.doi. org/10.5958/0974-360x.2015.00189.4

19. Abigail, Abigail, Priya J, Devi G. Evaluation of Muscular Endurance among Dentists [Internet]. Vol. 10, Indian Journal of Public Health Research \& Development. 2019. p. 258. Available from: http://dx.doi.org/10.5958/0976-5506.2019.02808.0

20. Shruthi M, Preetha S. Effect of Simple Tongue Exercises in Habitual Snorers [Internet]. Vol. 11, Research Journal of Pharmacy and Technology. 2018. p. 3614. Available from: http://dx.doi. org/10.5958/0974-360x.2018.00665.0

21. Iyer PK, Gayatri Devi R, Jothi Priya A. A Survey Study on Causes, Treatment and Prevention of Onychocryptosis [Internet]. Vol. 10, Indian Journal of Public Health Research \& Development. 2019. p. 807. Available from: http://dx.doi.org/10.5958/09765506.2019.01990.9

22. David, David, Jothi Priya A, Devi G. Physical Fitness among the Dental Physician, Dental Undergraduates and Postgraduates Students [Internet]. Vol. 10, Indian Journal of Public Health Research \& Development. 2019. p. 223. Available from: http:// dx.doi.org/10.5958/0976-5506.2019.02801.8

23. Dave PH, Preetha. Pathogenesis and Novel Drug for Treatment of Asthma-A Review. Research Journal of Pharmacy and Technology. 2016;9(9):1519-23.

24. $\mathrm{Rj}$ I, R GD. Role of environmental factors on sleep patterns of different age groups [Internet]. Vol. 9, Asian Journal of Pharmaceutical and Clinical Research. 2016. p. 124. Available from: http://dx.doi.org/10.22159/ajpcr.2016.v9i6.13832 
25. Choudhari S, Jothipriya MA. Non-alcoholic fatty liver disease [Internet]. Vol. 9, Research Journal of Pharmacy and Technology. 2016. p. 1782. Available from: http://dx.doi.org/10.5958/0974360x.2016.00360.7

26. R GD, Sethu G. EVALUATION OF ADENOIDS BY ORONASAL AND NASAL SPIROMETRY [Internet]. Vol. 11, Asian Journal of Pharmaceutical and Clinical Research. 2018. p. 272. Available from: http://dx.doi.org/10.22159/ajpcr.2018. v11i10.27365

27. Swathy S, Gowri Sethu V. Acupuncture and lower back pain [Internet]. Vol. 8, Research Journal of Pharmacy and Technology. 2015. p. 991. Available from: http://dx.doi.org/10.5958/0974360x.2015.00165.1

28. Renuka S, Sethu G. Regeneration after Myocardial Infarction [Internet]. Vol. 8, Research Journal of Pharmacy and Technology. 2015. p. 738. Available from: http://dx.doi.org/10.5958/0974360x.2015.00117.1

29. Timothy CN, Gayatri Devi R, Jothi Priya A. Evaluation of Peak Expiratory Flow Rate (PEFR) in Pet Owners [Internet]. Vol. 10, Indian Journal of Public Health Research \& Development. 2019. p. 803. Available from: http://dx.doi.org/10.5958/09765506.2019.01989.2

30. Qazi A, Qazi J, Naseer K, Zeeshan M, Hardaker G, Maitama JZ, et al. Analyzing situational awareness through public opinion to predict adoption of social distancing amid pandemic COVID-19 [Internet]. Journal of Medical Virology. 2020. Available from: http://dx.doi.org/10.1002/jmv.25840
31. Thangavel S, Pitchaimuthu A. An Awareness and Perception of COVID -19 among General Public - A Cross Sectional Analysis". 2020 Apr 1;6(4):49-53.

32. McKibbin WJ, Fernando R. The Global Macroeconomic Impacts of COVID-19: Seven Scenarios [Internet]. SSRN Electronic Journal. Available from: http://dx.doi.org/10.2139/ssrn.3547729

33. Turner AJ, Hiscox JA, Hooper NM. ACE2: from vasopeptidase to SARS virus receptor. Trends Pharmacol Sci. 2004 Jun;25(6):291-4.

34. Mukattash TL, Shara M, Jarab AS, Al-Azzam SI, Almaaytah A, Al Hamarneh YN. Public knowledge and awareness of cardiovascular disease and its risk factors: a cross-sectional study of 1000 Jordanians. Int J Pharm Pract. 2012 Dec;20(6):367-76.

35. Alhogbani T. Acute myocarditis associated with novel Middle east respiratory syndrome coronavirus. Ann Saudi Med. 2016 Jan;36(1):78-80.

36. Huang C, Wang Y, Li X, Ren L, Zhao J, Hu Y, et al. Clinical features of patients infected with 2019 novel coronavirus in Wuhan, China [Internet]. Vol. 395, The Lancet. 2020. p. 497-506. Available from: http://dx.doi.org/10.1016/s0140-6736(20)30183-5

37. Wang D, Hu B, Hu C, Zhu F, Liu X, Zhang J, et al. Clinical Characteristics of 138 Hospitalized Patients With 2019 Novel Coronavirus-Infected Pneumonia in Wuhan, China. JAMA [Internet]. 2020 Feb 7; Available from: http://dx.doi.org/10.1001/ jama.2020.1585 